\title{
MICROBIAL DIVERSITY IN BRAZILIAN MANGROVE SEDIMENTS - A MINI REVIEW
}

\section{Angela Michelato Ghizelini ${ }^{1 *}$, Leda Cristina Santana Mendonça-Hagler ${ }^{1}$, Andrew Macrae ${ }^{1,2 *}$}

${ }^{1}$ Programa de Pós Graduação em Biotecnologia Vegetal, Centro de Ciências da Saúde, Universidade Federal do Rio de Janeiro, RJ, Brasil; ${ }^{2}$ Instituto de Microbiologia Prof. Paulo de Góes, Universidade Federal do Rio de Janeiro, RJ, Brasil.

Submitted: November 08, 2011; Approved: June 07, 2012.

\begin{abstract}
The importance and protection of mangrove ecosystems has been recognized in Brazilian Federal law since 1965. Being protected in law, however, has not always guaranteed their protection in practice. Mangroves are found in coastal and estuarine locations, which are prime real estate for the growth of cities, ports and other economic activities important for Brazilian development. In this mini-review we introduce what mangroves are and why they are so important. We give a brief overview of the microbial diversity found in mangrove sediments and then focus on diversity studies from Brazilian mangroves. We highlight the breadth and depth of knowledge about mangrove microbial communities gained from studying Brazilian mangroves. We report on the exciting findings of molecular microbial ecology methods that have been very successfully applied to study bacterial communities. We note that there have been fewer studies that focus on fungal communities and that fungal diversity studies deserve more attention. The review ends with a look at how a combination of new molecular biology methods and isolation studies are being developed to monitor and conserve mangrove ecosystems and their associated microbial communities. These recent studies are having a global impact and we hope they will help to protect and re-establish mangrove ecosystems.
\end{abstract}

Key words: Mangroves, Biodiversity, Bacteria, Fungi, Brazil, Conservation, Ecology.

\section{INTRODUCTION}

Our objective is to emphasize the importance of the mangroves and mangrove microbial communities. We also intend to equip the reader with a good understanding of mangrove sediments and the current level of knowledge regarding their microbial communities using Brazilian case studies. Brazilian mangroves represent $8.5 \%$ of the global mangrove resource and arguably studies undertaken in Brazil are at the forefront of studies on mangrove sediment diversity, ecology and bioremediation. In the sections that follow, current knowledge on bacterial and fungal diversity of mangrove sediments is presented and discussed. Knowledge gaps for future studies are suggested.

\footnotetext{
*Corresponding Author. Mailing address: Programa de Pós Graduação em Biotecnologia Vegetal, Centro de Ciências da Saúde, Universidade Federal do Rio de Janeiro, RJ, Brasil.; E-mail: amacrae@biologia.ufri.br / angelamichelato@gmail.com
} 


\section{What are mangroves?}

Mangroves are coastal ecosystems, found in tropical and subtropical regions around the world. They are found in the transitional zones between land, sea and rivers (6, 35, 57); regarding their geographical distribution, mangroves are found in the Americas, Africa, Asia and Oceania $(35,56)$. Mangrove vegetation is found along $25 \%$ of the Earth's coastlines and $75 \%$ of tropical coastlines. Mangrove sediments are the foundation for mangrove forests and all that live in them. Life in mangroves requires special adaptations to survive in areas that are periodically inundated with sea water (54). Mangroves can be seen as the thin green line of vegetation around coasts and estuaries. Thin, because they account for less than $1 \%$ of the world's tropical forests and less than $0.4 \%$ of the total area of global forests. They are present in 123 countries and territories, covering about 152,000 $\mathrm{km}^{2}$ (64). Despite their wide distribution, more than two thirds of mangroves are found in just 12 countries. South America is home to $15.7 \%$ of the world's mangroves, only surpassed by Southeast Asia, with $33.5 \%$ (64). In Brazil, mangroves extend from the Cape Orange River Oiapoque $\left(04^{\circ} 30^{\prime} \mathrm{N}\right)$ to Laguna, Santa Catarina (28 ${ }^{\circ}$ 30 'S) (54). Brazil is the country with the second largest area of mangrove, covering $8.5 \%$ of the global total, or $13000 \mathrm{~km}^{2}$, second only to Indonesia, with 20.9 \% (64).

Unlike other tropical forests, mangroves forests are composed of a relatively small number of tree and shrub plant species (35). These plant species are specially adapted to fluctuating salinity and are capable of living in anoxic muddy sediments (57). Mangrove vegetation composition is controlled primarily by hydrology, geography and climate of the region. Plant morphological adaptations such as aerial roots facilitate life on and in the inter-tidal zone (4). Mangroves can tolerate a wide range of sediment types, temperature changes, nutrient, salinity and oxygen levels. Mangrove plant species vary in their tolerance to these factors, forming characteristic patterns or zones of vegetation (42). Spalding et al. (64) describe 73 species that inhabit mangroves. This seems to be a large number until a further look at their global distribution is considered. Spalding et al. (64) note that 62 species are found in the Indo-West Pacific realm and only 12 species in the Atlantic Eastern Pacific realm. In Brazil, there are only six plant species typical of mangroves belonging to three genera: Avicennia (Avicenniaceae), Laguncularia (Combretaceae) and Rhizophora (Rhizophoraceae) (6). On the other hand, the Brazilian Atlantic Rain Forest is home to 20.000 plant species of which $40 \%$ are endemic (7).

Although poor in plant diversity, many animal species inhabit mangroves including arthropods, fish, amphibians, reptiles, birds and mammals. These animals may spend all or part of their lives in the mangroves. Many animals use mangroves during reproductive periods or visit them from adjacent environments in order to find food $(35,54)$. Like the mangrove plants that characterize this ecosystem, many of these animals have adapted their morphology and physiology to survive in conditions unique to mangroves (57).

Different to most soils, pristine mangrove sediments are predominantly and persistently anaerobic. The fine fractions (mainly silt and clay size particles) dominate their texture combined with high concentrations of organic matter and salts (57). The tidal nature of mangroves impacts significantly on salinity and nutrients making them highly variable (29). Although these general traits are common, many other factors impact on sediment development including tidal range, local climates and substrate (46).

Mangroves play an important role in cycling energy and nutrients, and are vital exporters of organic matter to estuaries and coastal formations. They are wildlife refuges for both sea and terrestrial animals. They serve as natural shelters and nurseries for numerous aquatic organisms. This trait has guaranteed their use for fishing and cultivation of economically important species such as shrimp and prawns (6, 35, 63).

Given that mangroves are mostly tropical or close to the tropics, they receive a lot of solar energy. Light, abundant water, and nutrients from organic matter rich mud results in very high rates of biomass production. The net primary production (NPP) in mangroves is about $9.3 \mathrm{t} \mathrm{ha}^{-1}$ per year 
(64). This level of production makes mangrove forests one of the most productive ecosystems on the planet and about $50 \%$ more productive than other tropical forests that produce about $6 \mathrm{t} \mathrm{ha}^{-1}$ per year (64). Mangroves deposit large amounts of organic carbon to sediments, estuaries and the neighboring ocean. This in turn provides the basis for an enormous food web with the release of nutrients from the sediments mainly controlled by the microorganisms $(28,64)$.

Mangroves today are often found in or next to urban areas, where they are under the constant impact of anthropogenic activities. The continued growth of urban areas results in severe impacts on mangroves, modifying their hydrology, sediment and nutrient dynamics (40). Small-scale changes in the physical structure of mangrove forests can have significant effects on the diversity and abundance of wildlife in these environments (61). Such modifications may affect food webs causing irrevocable damage; which threatens their role as refuges, as nurseries, as well as foraging areas of marine fauna (61). Human activities affect the functioning and normally decrease the biodiversity of mangroves, thus leading to ecological imbalances and species extinction. With the development of urban centers, there has been a reduction in the area covered by mangroves. Irreversible damage occurs as a consequence of deforestation, land-filling and reclaiming coastal land for industry, housing, tourism and ports. According to Duke et al. (16), many mangroves are on the verge of extinction and are expected to disappear from at least 26 of the 120 countries in which they are currently found. Rates of destruction are currently measured at between 1 to $2 \%$ per year. Approximately 35,600 $\mathrm{km}^{2}$ of mangrove has been “lost” between 1980 and 2005. Even in the absence of accurate data on the original coverage of mangroves around the world, it is estimated that there was once approximately $200,000 \mathrm{~km}^{2}$ of mangrove and of that, about a quarter had been lost due to human activities. The destruction rate of these ecosystems is currently 3 to 5 times higher than the global rate for other types of forest loss (64). Estimates of mangrove deforestation are scarce in Latin America (37), however, it is known that besides the deforestation itself, the degradation of large areas of mangroves is occurring because of the improper use of coastal resources (37). Still, even with clear symptoms of stress (small tree size, fewer trees and loss of forest cover), mangroves are still frequently found in urban areas under chronic exposure to contamination by toxic recalcitrant compounds (22). A good example of a typical mangrove system is what remains in Guanabara Bay, Rio de Janeiro, Brazil. At the turn of the twentieth century mangroves covered $50 \mathrm{~km}^{2}$ of the bay's coastline (37). Unfortunately it is now almost totally degraded, with about $15 \mathrm{~km}^{2}$ of "less contaminated" forest remaining. In Guanabara bay, losses primarily resulted from reclaiming land, diverting streams and rivers and more recently due to oil spills, sewerage and solid waste disposal (37). Social and political needs have outweighed the need for protection and this situation is common globally.

The importance of mangroves to tropical coastal regions has been a continual source of scientific and political discussion. Recently IAI (American Institute for Global Change Research) have described mangroves as one of the most critical ecosystems in tropical region and vulnerable to global climate change (55). In 1965 Brazilian authorities recognized the importance of mangroves and gave them permanent protection in law (see Federal Law number 4771 9/15/65). However, since 1965, many areas of mangroves in Brazil have been destroyed and replaced with other activities of political and social importance. The failure of the 1965 law to protect mangroves did not go unnoticed and in 1985 further environmental laws were created to ensure their protection, including Resolution CONAMA $n^{\circ} 004$ (9/18/85) that establishes mangroves must be considered biological reserves and be protected. Even so, the protection of these areas still remains a challenge. Their unique ecology and ecological contribution is now better valued and to a greater extent understood and accepted, so is their impact on estuarine and coastal food webs. What still remains poorly understood are the microorganisms at the base of these food webs and their role in these ecosystems. In the next section we describe some of the 
microbial communities that have been studied. The ongoing aim is to understand who does what in such rich ecosystems and perhaps with that knowledge we will be able to harness the microbial power necessary to protect this type of ecosystem.

\section{Who is who in the microbial communities of mangrove sediments and are they important?}

Alongi (2) has made some interesting observations about microbial communities in mangrove sediments. We read that the total microbial biomass is never greater than $1.2 \%$ of the total mass of detritus. Bacteria and fungi make up about $91 \%$ of the total microbial biomass, while algae and protozoa represent $7 \%$ and $2 \%$, respectively in these ecosystems. The question remains: what are all they doing? Starting with bacteria, studies have shown that their role in mangroves is vital for biogeochemical cycles and transformations of most nutrients (35). Bacteria are among the largest contributors to carbon flux in these sediments $(3,27)$. The bacteria being the smallest occupy a greater variety of niches than the fungi, algae and protozoa and are seen as fundamental for the functioning of these habitats. Many of them are extremely important in controlling the chemical environment of the mangrove sediments and within anaerobic mud an important group is the sulfate-reducing bacteria. They are primary decomposers (41) of organic residues and fundamental for the carbon cycle. The bacteria are also the key players in nitrogen cycle involved in all its transformation from fixation, ammonification, nitrification and denitrification (1). Sherman et al. (58) have shown how nutrient availability in mangrove sediment controls vegetation species patterns in the inter-tidal zone. Given that microbes control nutrient availability, a link can thus be made between microbial communities in sediments and vegetation patterns.

There is a transition gradient from aerobic to anaerobic conditions in pristine mangrove sediments. On the surface, the sediments are aerobic but they become anaerobic very quickly and at shallow depths. This is a result of their fine texture and organic matter. The degradation of organic matter in the aerobic zone occurs mainly through aerobic respiration, and in the anaerobic layer decomposition occurs mainly through sulfate reduction $(45,58)$. Given that different bacterial taxonomic groups can share or have similar functional roles (30), the great diversity observed in sediments of mangrove ecosystem would suggest broad scale adaption and resilience to possible environmental impacts.

Human activities impact on mangroves, especially those activities associated with ports where diffuse oil and chemical spills are constant. Mangroves also receive agrochemical runoff delivered by larger rivers and sewerage. Where shallow fresh water meets deeper salt water and lower energy environments flocculation and sedimentation occurs and chemical cycling occurs. Complex communities, of bacteria and fungi, can biodegrade hydrocarbons in such environments (38). Microorganisms are often found in complex communities called biofilms where different species degrade different types of hydrocarbons found in petroleum. Sediments contaminated by oil and sewage can modify the natural processes of decomposition. Hydrocarbon degradation is considerably faster under aerobic conditions and covering sediments with heavy oil can quickly create anaerobic conditions. Under anaerobic conditions, oil degradation is less efficient and can result in the release of toxic sulfates (28). LaMontagne et al. (38) and others $(10,18)$ have shown that the composition of inputs and levels of hydrocarbons in sediments can influence the composition of bacterial communities. Santos et al. (51) published a review on the potential and challenges faced for bioremediation of wetlands and mangrove sediment impacted by oil.

In soils the role and importance of the fungi in converting lignin and cellulose into less stable carbon forms is well documented and it is similar in mangrove sediments. The combination of bacteria and fungi in aerobic communities results in the rapid oxidation of organic material and carbon recycling. Fungi are efficient in synthesizing enzymes involved in non-specific degradation of cellulose and lignin. However, in sediments and under anaerobic conditions their role and importance is not so clearly defined (19). Like the bacteria, the 
fungi are ubiquitous. Their tiny spores are dispersed by the wind and environmental conditions will select the groups that will prosper $(17,50,68)$. Successful colonization and high fungal biodiversity is favored by moist conditions, environments rich in organic matter, aeration and low $\mathrm{pH}$ amongst other factors. Though potentially ubiquitous, some fungal species are restricted to very specific niches and are endemic, especially the symbiotic and parasitic forms (25). Marine sediments are inhabited by fungi. They are found in shallow coastal sediments as well as in deep sea sediments (50) and also are common in mangrove sediments (50). Studies suggest that about half of the fungi in sediments are absorbed to sediment particles and are difficult to detect. The remainder, are present in the interstitial water between organic and inorganic sediment particles. Fungal numbers and biomass varies with the type of sediment, with larger numbers seen in shallow coastal regions and biomass decreasing rapidly with depth. Coarser sandy sediments have lower numbers of fungi than do sediments of finer texture (50). Their primary role is considered to be the mineralization of organic matter, and they are also a food source for benthic fauna (50).

The tropical micro-fungi represent a universe of unexplored biodiversity, producing a wide range of enzymes that can degrade many types of organic and inorganic substrates (31). Micro-fungi that have been found in mangrove forests are also diverse and are present in this ecosystem as epiphytic, polisaprobial and pathogens in different organic and inorganic substrates, in the sediment and on leaves, stems, fruits, roots and animals (31). Fungi including: ascomycetes, mitosporic fungi, basidiomycetes, chitridiomycetes, myxocycetes, oomycetes, thraustochitrids and zygomycetes have been reported as present in mangrove forests from around the World (65). Many of these fungi are of terrestrial origin, and basidiomycetes, ascomycetes and deuteromycetes are most predominant (33), however finer taxonomic resolution at family, genus and strain levels is required.

\section{Bioprospecting, how are microbes from mangrove}

\section{sediments studied?}

Mangrove sediments, owing to their peculiar characteristics, have long since caught the attention of researches exploring fungal diversity. Jaitly and Rai (32) suggest that mangrove sediments should be explored for biotechnology applications and highlighted thermophilic and thermotolerant fungi as good targets. High temperatures, high levels of salinity, high $\mathrm{pH}$, high levels of organic matter, low aeration and moisture provide interesting substrate conditions conducive to the development of diverse fungi, with biotechnology potential $(14,60)$. To explore microbial diversity two groups of methods are generally employed: Culture Dependent and Culture Independent methods. In the last two decades the culture independent/molecular biology methods have revolutionized our knowledge of microbial diversity. Ribosomal RNA gene sequences, amongst others gene sequences, provide signatures or bar codes that confirm the presence of hugely diverse microbial communities in sediments and soils. Metagenomics, Genomics, Proteomics and now Transcriptomics facilitated by recent advances in bioinformatics and sequencing technologies have given us a much better idea of global alpha biodiversity and functional diversity. What the new methods do not tell us yet is who is doing what in a particular environment, why and which groups of organisms are driving processes at any given time. We have learned to say with some confidence who is at the party and what is happening at the party but not necessarily who did what!

To determine the composition, activity, function and importance of different components of microbial communities in natural environments continues to be a great challenge. While the non-culture methods have opened our eyes to hitherto untold diversity we are still struggling to develop culture dependent methods that create conditions that successfully mimic natural environments. If we are to harness the power of microbial processes there is need to isolate components of functionally important communities. The structure of these microbial communities is highly complex due 
to the infinitely large number of infinitely small niches that microbes can inhabit. Increasingly, it is becoming clear that unicellular organisms frequently choose a multi-cellular life form which can be as populations, guilds or mixed communities thus making it difficult to characterize these communities. Martins et al. (44) have demonstrated this phenomenon to great effect with microscopy and magnetotactic bacteria from Brazilian sediments. Intercellular communication is an important part of understanding function and seemingly there is a symphony of signals out with our current understanding. The non-culture methods have re-written our knowledge of alpha diversity which was previously based on conventional methods of culturing. While conventional methods of isolation limit the diversity found to the artificial conditions created in the laboratory, they do provide living organisms and an opportunity to study and manipulate microbial physiology. Polyphasic approaches that combine conventional and molecular techniques have expanded the knowledge of the specific and functional diversity of microorganisms in natural environments and it is to these we turn now.

\section{Microbial communities found in Brazilian sediments}

Many of the studies that have been published about Brazilian mangroves have been from chronically contaminated environments, and the vast majority of the work has concentrated on mangroves in the industrial Southeast of Brazil. The mangrove ecosystem that has been most studied are the remains of mangrove forest around the coastline of Guanabara Bay. The history of development in the vicinity of the bay is the history of the development of Rio de Janeiro, but not only Rio, also Sydney in Australia, and many other coastal (once capital) cities in the tropics. It is the story of the river that meets sea and is inhabited by mankind who needs the river, bay and shore for social and economic development at a cost to the natural environment. Development of large coastal cities has, however, kept mangrove destruction in the public eye which has helped move politicians to create laws to protect mangroves in other areas. Very significant investments and scientific effort have been made in order to understand and restore degraded mangroves. This effort can be measured by a web of Science and PubMed search that reveals that more than 6000 scientific papers have been published about mangroves.

Back in Guanabara Bay, Crapez et al. (12), Brito et al. (8, 9) and Wasserman et al. (68) described the bioremediation potential of microorganisms capable of degrading persistent organisms pollutants found in the bay. Unfortunately, their study like too many other studies just looked at the mangroves fragments that remain within the Guanabara Bay without comparing their results with a pristine mangrove or one that has suffered relatively little impact. To understand the importance and scale of this we look to the studies of MacielSouza et al. (43) which compared mangrove data from within the Guanabarra Bay with data from another less impacted mangrove outside the bay. Three mangrove sites within the bay were compared with the mangrove at 'Restinga da Marambaia'. The results show that the number of heterotrophic bacteria isolated from the mangrove sediment found at Marambaia was three orders of magnitude higher than in the mangroves chronically contaminated by oil and sewage, located in Guanabara Bay. The presence of pollutants had very negative affects on the abundance of bacteria in polluted environments. Accepting the inherent limits of culture based methods, microbial counts were also performed for hydrocarbon degrading bacteria. Here the degraded sediments had one order of magnitude higher counts than the pristine environment. In a simple experiment we see that even though there were fewer bacteria in the degraded sediments, there were more of them adapted to degrade hydrocarbons when compared with the pristine environment. It is noteworthy that the levels of polycyclic aromatic hydrocarbon (PAHs) found in sampling points located near Duque de Caxias city, in the Guanabara Bay, were and probably still are amongst the highest cited in scientific literature anywhere in the world (43). PAHs were not detected in the sediment from Marambaia.

Sediment contamination with petroleum hydrocarbons is 
especially dangerous for mangrove forests because aromatic hydrocarbons of low molecular weight (as benzene, toluene, ethylbenzene, and xylene - BTEX - , naphthalene and phenanthrene) are phyto-toxic and affect all stages of plant growth (26, 36, 49, 51). Santos et al. (51) provide a useful review of studies on the degradation of hydrocarbons and BTEX in mangroves.

From the literature we see that the methods commonly used for microbial bioprospection are based on the isolation of microorganisms from contaminated areas on a selective media enriched in the pollutant of interest. Molecular techniques are then used for accurate identification of strains that have been isolated $(13,34)$. Thereafter microbial inoculants based on one organism, or a mixture of organisms, can be applied to the sediment and pollution levels monitored. Successful bioremediation can be measured in terms of increased plant growth and or decreasing levels of pollutant.

A good example of a very interesting approach is seen in the study by Dias et al. (15) where bacterial diversity present in mangrove sediments from Cardoso Island, located in São Paulo were studied. Dias et al. (15), used culture-independent molecular approaches (Denaturing Gradient Gel Electrophoresis and sequence analysis of a cloned DNA library) to assess the bacterial communities present in the sampled area. They analyzed the DGGE profiles of total bacterial community samples from sediments in order to find community patterns from which to infer causal agents that affect the structure of bacterial communities. In other words, they sought to reveal how changes in organic matter content, $\mathrm{pH}$, conductivity and nutrients, can lead to changes in the composition of bacterial communities, depending on the sample point location, depth, specimen collection, as well as seasonality. Their DGGE profiles (microbial community bar codes) showed that the dominant low-density communities were sensitive to changes in environmental factors. Their results also revealed that sample point location was crucial to detect the presence of all taxonomic groups within the community. Seasonality affected the Alphaproteobacteria and
Betaproteobacteria. Sample depth influenced the Alphaproteobacteria and Actinobacteria community profiles. The importance of site location for all groups was explained to some extent, by changes in site specific variables such as $\mathrm{pH}$, salinity, organic matter content, conductivity, and the amount of nutrients. Sequences analysis revealed a bacterial community dominated by Alphaproteobacteria, Gammaproteobacteria and Acidobacteria, while less dominant groups were made up of the Betaproteobacteria, Deltaproteobacteria, Firmicutes, Actinobacteria and Bacteroidetes. The authors suggested that their results indicate adaptive plasticity and that in the mangrove sediments the Alphaproteobacteria are the dominant group.

These results support earlier work that described the limited diversity of Betaproteobacteria and Actinobacteria in mangrove sediment located in Rio de Janeiro (21). Gomes et al. (21) emphasized that anthropogenic effects did not completely change the dominant bacterial groups, but might interfere with less dominant bacterial groups. Gomes et al. (21) also evaluated bacterial community profiles by DGGE. They studied three sites within Guanabara Bay and their results confirm the importance of site location to explain microbial community profiles and differences in communities between sites. They found that each location produced a different community profile with different relative contributions of bacterial groups. What was important to note was that the culture independent molecular methods provide a snapshot of complex and diverse communities. It is not therefore very surprising that variability between sites in this type of study is more often seen than not. The bacterial profiles were significantly different for the three areas sampled. Gomes et al. (21) then undertook a culture dependent approach. They isolated a broad range of bacteria from all three locations that were capable of degrading PAHs including from the least polluted site.

These studies indicated that anthropogenic influences did affect mangrove sediment bacterial communities, especially less abundant taxonomic groups and that those affects might 
significantly change ecosystem functioning.

The most recent mangrove studies have focused on identifying the microbial groups that are indicators of hydrocarbon pollution in mangrove ecosystems. In this case the presence or absence of a key tax or the proliferation of other taxa may be used to infer pollution and monitor recuperation (53). 454 pirosequencing of PCR amplified 16S rDNA was used to identify candidate groups in microcosms filled with sediment from the pristine Marambaia Mangrove. Santos et al. (53) reported that the group Chromatiales and the genus Haliea were sensitive to the presence of oil, while the genera Marinobacterium, Marinobacter and Cycloclasticus were detected in greater numbers in the presence of oil. Their findings provide target organisms for monitoring oil spills in mangrove environments. In a different study by the same research group, Peixoto et al. (47) showed that the occurrence of bacterial communities did correlate with the spatial distribution of petroleum pollutants in mangrove sediments. Those results are supported by the findings of Santos et al. (53) that indicated that certain microbial groups can serve as bioindicators of oil pollution and that perhaps can help identify which pollutants are present. Peixoto et al. (47) studied the spatial distribution of bacterial communities in mangrove sediments by multivariate analysis of bacterial community profiles generated by DGGE. They also used conventional culture based methods and CFU counts $\left(10^{6}\right.$ to $10^{8}$ cells.g $^{-1}$ of sediment or rizhosphere) and found that counts were significantly correlated with the conditions and chemical pollutants in sediments sampled. Furthermore, they determined the biotechnological potential of 364 isolates, of which $70 \%$ were able to grow in the presence of oil as a sole carbon source. Their results reinforce earlier findings seen by MacielSousa et al. (43). Namely, what we see is that communities respond to polluted environments exploiting their inherently huge metabolic potential and adapt according to chemical and environmental conditions in mangrove sediments.

In a study from Bahia in the North East of Brazil, Taketani et al. (66) analyzed the response of a microbial community in mangrove sediment at different levels of oil pollution. They studied two sediments from within the Todos os Santos Bay (Bahia), one sediment with a documented history of contamination and the other without. They contaminated small amounts of each sediment and studied Kingdom level responses from the Eubacterial and Archaeal communities. Community profiles were very different between the two sites and this was interpreted in evolutionary terms using disturbance theory. The polluted site has been repeatedly polluted/disturbed and the dominant microbial communities detected by the DGGE analysis were a reflection of multiple adaptations to disturbances and a succession of changes. The addition of oil to a frequently contaminated sediment can be understood as just one more disturbance and perhaps it would be surprising to expect that such diverse communities would converge to similar community structures after just one oil spill. Not satisfied with studying only the archaea and eubacteria, Taketani et al. (67) also studied the diversity of sulfate-reducing bacteria in sediments of mangroves using the $d s r \mathrm{~B}$ gene. Interestingly $d s r \mathrm{~B}$ gene banding intensity (abundance) and richness / diversity (number of bands on a DGGE profile) decreased with depth which was explained by variations in the environment.

It is apparent that oil (a mixture of PAHs) contamination is frequent and variable in mangroves. Culture dependent count methods repeatedly indicate $(43,47)$ that microbial numbers decline in more heavily polluted sites and that communities change and functional groups enrich in response to a pollutant. Culture independent analyses, especially DGGE, provide community profiles/fingerprints and indicate that changes in communities are most often site-specific; and are dependent on site specific environmental conditions at each location that are not easily predictable nor reproducible. This level of complexity is not surprising and it is seen on land in almost all soil diversity studies. Given that at an operational/experimental level microbial diversity is difficult to measure, then from an environmental engineer's point of view microbial function is more important than which taxonomic groups are carrying out 
a specific function. For those tasked with restoring and reforesting mangroves, as well as protecting environments from further pollution, there is a strong case to focus on the functional diversity within mangrove sediments. In the first deep study to try understanding functional diversity of PAH biodegrading genes in the Guanabara Bay, Gomes et al. (22) used PCR and DGGE of naphthalene dioxygenase (ndo) genes as well as Southern blotting of other functional genes to try and measure functional diversity. Not surprisingly genes were amplified from the most contaminated sites near the REDUC refinery but more interestingly a greater diversity of degrading genes were identified from a site with less contamination located at the APA Guapimirim. Reassuringly there were an abundance of genes associated with $\mathrm{PAH}$ degradation but the fact that the most contaminated site had a less diverse range of genes would suggest that toxicity thresholds were restricting the range of bacteria and degradation genes at that site next to the refinery. One might argue that Gomes et al. (22) study has identified a functional diversity threshold for ndo genes. This then is similar but different to the Santos et al. (53) study which identified key taxa for monitoring oil pollution. The findings of Gomes et al. (22) could also be described as having identified biomarkers for functional thresholds. Gomes et al. (24) went on to identify functional plasmids and genes from those sediments that are important for the decontamination of petroleum hydrocarbon contaminated sediments and rhizospheres. The rhizosphere is that zone of soil or sediment around a plant root under chemical and physical influence of the root. Mangrove ecosystems are characterized by very few tree species and the chemical exchanges at their root-sediment interface are critical for their survival. The role of microbes in degrading toxic low molecular weight hydrocarbons next to plant roots in mangroves is seen as essential for their survival. On-going studies (48) have demonstrated that when oil levels reach 5\% in sediments then Brazilian mangrove tree species will not grow and most will die. Gomes et al. (24) undertook to understand rhizosphere microniches and manipulated native microbial populations from sediments to degrade PAHs. They found weak positive signals for specific types of functional genes in untreated sediment confirming their presence. Then a consortium of microbes washed from plants roots was incubated with PAHs and later returned to the sediment. Sediment and rhizosphere samples were extracted and hydrocarbon degrading plasmids were detected including the IncP-1a, IncP-1b and RIP IncP-7-9 plasmids. Functional genes for the degradation of naphthalene, and an extradiol intradiol dioxygenase were also detected. These results show that despite the low abundance of hydrocarbon degrading genes and plasmids (below normal detection levels without enrichment), they could be manipulated and detected in the sediment samples. The study also showed that the functional capacity was naturally present and that it could be increased to function at detectable levels. The research demonstrated that native microorganisms can be manipulated in a desired fashion and returned to the natural environment to increase the $\mathrm{PAH}$ degrading capacity of a mangrove sediment. Functional diversity was shown to be positively manipulated in mangrove sediments and a question that now remains is which other interesting genes are present and as yet undetected in these sediments?

Dias et al. (14) isolated, from a mangrove in Cananéia (SP), bacteria of the Vibrionales group, ubiquitous microbes in marine and estuarine environments and demonstrated diverse enzymatic production (amilase, protease, esterase and lipase) from these isolates. Couto et al. (11) isolated and characterized a novel gene that encodes an important lipase, LipA, from a metagenomic library extracted from the sediment of a mangrove forest located in the 'Pontal do Paraná', Paraná. The LipA is part of a set of enzymes with biotechnological applications because of its broad substrate specificity, high selectivity and stability in organic solvents and that it does not need cofactors to work. These results are encouraging and confirm that bacteria from mangroves sediments are a potential source of new biocatalysts. The reports by Dias et al. (14) and Couto et al. (11) are two of potentially many novel studies that demonstrate the biotechnological value of microbial 
communities in mangrove sediments. Using a metagenomics approach for bioprospecting it was possible to isolate a novel peculiar lipase which can be cloned and employed as a new biocatalysts.

\section{But what about the fungi?}

In comparison with studies on bacteria very little has been published in refereed journals about fungi present in mangrove sediments globally, let alone in Brazil. The molecular / culture independent methods that have been widely used to study bacteria have not yet been reported on the same scale for the fungi. What we do find in the literature are a relatively small number of diversity studies based on culture methods. Soares et al. (62) isolated yeasts from mangrove sediments in Rio de Janeiro and found 47 species, mostly belonging to the genus Candida. Pathogenic species were detected, mainly coming from sewerage polluted areas. In addition, they found large differences in diversity between the sampling sites in one mangrove sediment and that those differences were far greater than between site sampling from other types of ecosystems found in the same geographic region. Recently Araújo and Hagler (5) have reported on yeasts isolated from mangrove sediments from four sites in the State of Rio de Janeiro, two highly impacted and two better-preserved. They also observed a wide variety of yeasts, and also detected differences in abundance and diversity between the sampling sites. A possible explanation given was the presence of pollutants in these environments (yeasts from the Coroa Grande’s mangrove, the more polluted area, were more diverse and abundant than yeast from the Suruí's mangrove). Using conventional methodology and DNA sequencing techniques they described 29 genera. Candida was also the most frequent and the presence of pathogenic species which would indicate the presence of fecal contamination were also reported. They identified Kluyveromyces aestuarii as a typical inhabitant of mangroves, a result similar to that found by Soares et al. (62). Silva (59) isolated fungi from estuarine sediments near Santos (São Paulo) belonging to the following groups: ascomycetes, basidiomycetes, zygomycetes and mitosporic, which were found to be tolerant to phenanthrene and pyrene. Cyclothryrium sp., Penicillium simplicissimum and Psilocybe sp. were able to degrade these compounds and Cyclothryrium sp. was the most effective. Gomes et al. (20) isolated and identified 50 species of filamentous fungi from the mangrove sediments of Barra das Jangadas, Jaboatão dos Guararapes, Pernambuco, in the Northeast of Brazil. The genera of fungi found were considered to be of terrestrial origin indicating adaptation to the variable conditions found in mangroves. They found that Penicillium and Aspergillus were the dominant genera, followed by Trichoderma, Fusarium, Phoma, Talaromyces, Cladosporium, Eupenicillium, Gongronella, Microsphaeropsis, Mucor, Stilbella and Thielavia. Species from Gongronella butleri and Stilbella clavispora were recorded for the first time in Brazilian mangroves. That study provides a bench mark study for future studies and it is of special note. Santos et al. (52) using, a molecular approach, were the first to describe relative changes in fungal diversity in mangrove sediments in response to other PCR amplified groups. Using PCR-DGGE they found that about $70 \%$ of the 18S rDNA sequences recovered in pristine sediments were from microeucaryotic fungi. In their microcosm study they demonstrated that adding oil to a microcosm and polluting the sediment resulted in a significant decrease in the relative abundance of fungi. They highlight the potential role of microeucaryotes as biomarkers for pollution. The next step from that study would be to evaluate the groups identified by Santos et al. (52) and test samples from other mangrove sediments to see if they are reproducible and represent thresholds species for pollution levels.

The recent studies by Santos et al. $(52,53)$ and Peixoto et al. (47) have had an international impact on our global understanding of mangrove sediment biodiversity. The use of high throughput sequencing is currently the unrivalled technique to describe alpha biodiversity from any environment and this has been successfully done for bacteria in mangrove sediments by Santos et al. (53). Further studies using this 
technique will be very welcome because the DGGE studies have clearly shown us just how variable bacterial communities are in mangrove environments. From each new study we learn something new about that location. DGGE is now probably better employed to describe functional gene distributions and to help us understand and manipulate function. Soon we will see transcriptome analyses from environmental samples including mangroves sediments. The quantity of information will be colossal and no doubt it will be complex and difficult to meaningfully interpret and apply. The DGGE and functional gene studies by Gomes $(22,24)$ have also had a global impact on how to approach bioremediation in mangrove sediments. They successfully link scientific discovery with practical applications by understanding the need to manipulate mangrove sediment function. In writing this mini-review what is alarming and abundantly clear is how little has been published about the fungal communities in mangrove sediments. There are a number of reasons for this, including the fact that short fragments of ribosomal DNA so frequently used to describe bacterial diversity are too conserved to adequately describe fungal diversity. There is also a real need to refine and agree the molecular markers (genes) for fungal taxonomy. Agreement is required so that molecular methods can be effectively used to identify diversity as has been done for the prokaryotes. At this time there is a need for culture dependent techniques to be applied to mangrove sediments to create collections of fungi from this ecosystem. In this mini- review perhaps the most interesting findings on mangrove sediment diversity and function have come from microcosm studies where a hypothesis has been tested and an attempt to understand physiology has been made. Mangroves are plant driven ecosystems and in Brazil, different to Asian mangroves in Brazil these ecosystems often depend on just three tree species. These three species are resilient but not invincible. The microbial diversity seen in mangrove sediments has its own intrinsic value but we must not forget that it has evolved with a limited set of tree species and still resulted in an organic biogeochemical web of untold potential. Santos et al. (51), in a review on mangrove pollution, correctly recognize that the mangrove trees are themselves the most easily recognizable indicators of mangrove health. Studies from that group are developing inoculants of plant growth promoting bacteria that degrade PAHs in the hope that a microbial boost will help mangrove plants re-establish in the areas that have been lost. Recent (23) and high impact studies cited in this mini-review herald a brighter future for Brazilian mangroves.

\section{REFERENCES}

1. Abraham, T.J.; Ghosh, S.; Nagesh, T.; Sasmal, D. (2004). Distribution of bacteria involved in nitrogen and sulfur cycles in shrimp culture systems of West Bengal, India. Aquacult. 239, 275-288.

2. Alongi, D.M. (2002). Present state and future of the world's mangrove forests. Environ. Conser. 29 (3), 331-349.

3. Alongi, D.M.; Christoffersen, P.; Tirendi, F. (1993). The influence of forest type on microbial-nutrient relationship in tropical mangrove sediments. J. Exp. Mar. Biol. Ecol. 171, 201-223.

4. Araújo, D.S.D.; Maciel, N.C. (1979). Os manguezais do Recôncavo da Baía de Guanabara. Cadernos FEEMA, série técnica n.10, RJ. 113p.

5. Araújo, F.V.; Hagler, A.N. (2010) Leveduras associadas a sedimentos de manguezais no Estado do Rio de Janeiro, Brasil. Rev. Gest. Cost. Integr. 8 (n ${ }^{\circ}$ esp.2), 1-9.

6. Barros, H.M.; Macedo, S.J.; Eskinazi-Leça, T.L.; Lima, T. (2000). Gerenciamento participativo de estuários e manguezais. Editora Universitária da UFPE, Recife. 252p.

7. Brandon, k.; Fonseca, G.A.B.; Rylands, A.B.; Silva, J.M. (2005). Conservação brasileira: desafios e oportunidades. Megadiversidade. 1(1), 7-13.

8. Brito, E.M.S.; Duran, R.; Guyoneaud, R.; Goñi-Urriza, M.; Oteyza, T.G.; Crapez, M.A.C.; Aleluia, I.; Wasserman, J.C.A. (2009). A case study of in situ oil contamination in a mangrove swamp (Rio de Janeiro, Brazil). Mar. Poll. Bull. 58, 418-423.

9. Brito, E.M.; Guyoneaud, R.; Goni-Urriza, M.; Ranchou-Peyruse, A.; Verbaere, A.; Crapez, M.A.; Wasserman, J.C.; Duran, R. (2006). Characterization of hydrocarbonoclastic bacterial communities from mangrove sediments in Guanabara Bay, Brazil. Res. Microb. 157, 752762. 2006.

10. Castle, D.M.; Montgomery, M.T.; Kirchman, D.L. (2006). Effects of naphthalene on microbial community composition in the Delaware estuary. FEMS Microb. Ecol. 56 (1), 55-63.

11. Couto, G.H.; Glogauer, A.; Faoro, H.; Chubatsu, L.S.; Souza, E.M.; Pedrosa, F.O. (2010). Isolation of a novel lipase from a metagenomic library derived from mangrove sediment from the south Brazilian coast. 
Genet. Mol. Res. 9 (1), 514-523.

12. Crapez, M.A.C.; Tosta, Z.T.; Bispo, M.G.S.; Pereira, D.C. (2000). Acute and chronic impacts caused by aromatics hydrocarbons on bacterial communities at Boa Viagem and Forte do Rio Branco Beaches, Guanabara Bay, Brazil. Environ.l Poll.108, 291-295.

13. Desaint, S.; Hartmann, A.; Parekh, N.R.; Fournier, F.C. (2000). Genetic diversity of carbofuran-degrading soil bacteria. FEMS Microb. Ecol. 34, 173-180.

14. Dias, A.C.F.; Andreote, F.D.; Andreote, F.D.; Laçava, P.T.; Sá, A.L.B.; Melo, I.S.; Azevedo, J.L.; Araújo, W.L. (2009). Diversity and biotechnological potential of culturable bacteria from Brazilian mangrove sediment. World J. Microbiol. Biotechnol. 25, 1305-1311.

15. Dias, A.C.F.; Andreote, F.D.; Rigonato, J.; Fiore, M.F.; Melo, I.S.; Araújo, W.L. (2010). The bacterial diversity in Brazilian non-disturbed mangrove sediment. Antonie van Leeuwenhoek, 98, 541-551.

16. Duke, N.C.; Meynecke, J.O.; Dittmann, S.; Ellison, A.M.; Anger, K.; Berger, U.; Cannicci, S.; Diele, K.; Ewel, K.C.; Field, C.D.; Koedam, N.; Lee, S.Y.; Marchand, C.; Nordhaus, I.; Dahdouh-Guebas, F. (2007). A world without mangroves? Science, 317, 41-42.

17. Espósito, E.; Azevedo, J.L. (2010). Fungos: Biologia, Bioquímica e Biotecnologia. Caxias do Sul: Educs. 2 ed. 638p.

18. Girvan, M.S.; Campbell, C.D.; Killham, K.; Prosser, J.I.; Glover, L.A. (2005). Bacterial diversity promotes community stability and functional resilience after perturbation. Environ. Microb. 7 (3), 301-313.

19. Gofar, N. (2011). Characterization of petroleum hydrocarbon decomposing fungi isolated from mangrove rhizosphere. J. Trop. Soils, 16(1), 39-45.

20. Gomes, D.N.F.; Cavalcanti, M.A.Q.; Passavante, J.Z.O. (2011). Fungos filamentosos isolados de sedimento do manguezal Barra das Jangadas, Jaboatão dos Guararapes, Pernambuco, Brasil. Trop.Oceanogr. 39 (1), 36-45.

21. Gomes, N.C.M.; Borges, L.R.; Paranhos, R.; Pinto, F.N.; MendonçaHagler, L.C.S.; Smalla, K. (2008). Exploring the diversity of bacterial communities in sediments of urban mangrove forests. FEMS Microb. Ecol. 66, 96-109.

22. Gomes, N.C.M.; Borges, L.R.; Paranhos, R.; Pinto, F.N.; Krögerrecklenfort, E.; Mendonça-Hagler, L.C.S.; Smalla, K. (2007). Diversity of ndo genes in mangrove sediments exposed to different sources of polycyclic aromatic hydrocarbon pollution. Appl. Environ. Microb. 73, 7392-7399.

23. Gomes, N.C.M.; Cleary, D.F.R.; Pinto, F.N.; Egas, C.; Almeida, A.; Cunha, A.; Mendonça-Hagler, L.C.S.; Smalla, K. (2010). Taking Root: Enduring effect of rhizosphere bacterial colonization in mangroves. PLoS ONE, 5(11), e14065. doi:10.1371/journal.pone.0014065.

24. Gomes, N.C.M.; Flocco, C.G.; Costa, R., Junca, H.; Vilchez, R.; Pieper, D.H.; Krögerrecklenfort, E.; Paranhos, R.; Mendonça-Hagler, L.C.S.; Smalla, K. (2010). Mangrove microniches determine the structural and functional diversity of enriched petroleum hydrocarbon-degrading consortia. FEMS Microb. Ecol. 74 (2), 276-290.

25. Herrera, T.; Ulloa, M. (1990). El Reino de los Hongos: Micologia básica y aplicada. Ciudad Universitaria, México: Universidade Nacional Autónoma do México; Fondo de Cultura Econômica. 552p.

26. Hoff, R. (2002). Mangrove recovery and restoration. In: Hoff, R. (Ed.). Oil Spills in Mangroves - Planning \& response considerations. National Oceanic and Atmospheric Administration, NOAA Ocean Service, Office of Response and Restoration. pp 44-55.

27. Holguin, G.; Bashan, Y.; Mendonza-Salgado, R.A.; Amador, E.; Toledo, G.; Vazquez, P.; Amador, A. (1999). La microbiología de los manglares. Bosques en la frontera entre el mar y la tierra. Cienc. Desarr. 144, 26-35.

28. Holguin, G.; Bashan, Y.; Vazquez, P. (2001). The role of sediment microorganisms in the productivity, conservation, and rehabilitation of mangrove ecosystems: an overview. Biol. Fert. Soils, 33, 265-278.

29. Holguin, G.; Gonzalez-Zamorano, P.; Bashan, L.E.; Mendoza, R.; Amador, E.; Bashan, Y. (2006). Mangrove health in an arid environment encroached by urban development - a case study. Sci. Total Environ. 363, 260-274.

30. Hooper, D.U.; Chapin, F.S.; Ewell, J.J.; Hector, A.; Inchausti, P.; Lavorel, S.; Lawton, J.H.; Lodge, D.M.; Loreau, M.; Naeem, S.; Schmid, B.; Setälä, H.; Symstad, A.J.; Vandermeer, J.; Wardle, D.A. (2005). Effects of biodiversity on ecosystem functioning: a consensus of current knowledge. Ecolog. Monog. 75, 3-35.

31. Hyde, K.D. (1997). Biodiversity of tropical microfungi. The Hong Kong University Press, Hong Kong.

32. Jaitly, A.K.; Raí, J.N. (1982). Termophilic and thermotolerant fungi isolated from mangroves swamps. Mycol. 6 (74), 1021-1022.

33. Jones, E.B.G.; Alias, S.A. (1997). Biodiversity of Mangrove Fungi. In: Hyde, K.D. (Ed.) Biodiversity of Tropical Microfungi. Hong Kong University Press, Hong Kong, pp.71-92.

34. Kamagata, Y.; Fulthorpe, R.R.; Tamura, K.; Takami, H.; Forney, L.J.; Tiedje, J.M. (1997). Pristine environments harbor a new group of oligotrophic 2,4-dichlorophenoxiacetic acid-degrading bacteria. Appl. Environ. Microb. 63(6), 2266-2272.

35. Kathiresan, K.; Bingham, B.L. (2001). Biology of mangroves and mangrove ecosystems. Adv. Mar. Biol. 40, 81-251.

36. Kummerová, M.; Kmentová, E. (2004). Photoinduced toxicity of fluoranthene on germination and early development of plant seedling. Chemosphere, 5, 387-393.

37. Lacerda, L.D.; Conde, J.E.; Kjerfve, B.; Alvarez-León, R.; Alarcón, C.; Polanía, J. (2002). American mangroves. In: Lacerda, L.D. (ed.). Mangrove ecosystems. Springer Verlag: Berlim. pp.1-62.

38. LaMontagne, M.G.; Leifer, I.; Bergmann, S.; Van De Werfhorst, L.C.; Holden, P.A. (2004). Bacterial diversity in marine hydrocarbon seep sediments. Environ. Microb. 6, 879-808.

39. Leahy, J.G.; Colwell, R.R. (1990). Microbial degradation of 
hydrocarbons in the environment. Microbiol. Rev. 54(3), 305-315.

40. Lee, S.Y.; Dunn, R.J.K.; Young, R.A.; Connolly, R.M.; Dale, P.E.R.; Dehayr, R.; Lemckert, C.J.; Mckinnon, S.; Powell, B.; Teasdale, P.R.; Welsh, D.T. (2006). Impact of urbanization on coastal wetland structure and function. Aust. Ecol. 31, 149-163.

41. Loka Bharathi, P.A.; Oak, S.; Chandramohan, D. (1991). Sulfate reducing bacteria from mangrove swamps. 2. Their ecology and physiology. Oceanol. Acta, 14, 163-171.

42. Lovelock, C. (1993). Field Guide to the Mangroves of Queensland. Australian Institute of Marine Science, Townsville, Queensland. 72p.

43. Maciel-Souza, M.C.; Macrae, A.; Volpon, A.G.T.; Ferreira, P.S.; Mendonça-Hagler, L.C.S. (2006). Chemical and microbiological characterization of mangrove sediments after a large oil-spill in Guanabara Bay - RJ - Brazil. Braz. J. Microb. 37, 262-266.

44. Martins, J.L.; Silveira, T.S.; Silva, K.T.; Lins, U. (2009). Salinity dependence on the distribution of magnetotactic multicellular prokaryotes in a hypersaline lagoon. Intern. Microb.12, 193-201.

45. Nedwell, D.B.; Blackburn, T.H.; Wiebe, W.J. (1994). Dynamic nature of the turnover of organic carbon, nitrogen and sulphur in the sediments of a Jamaican mangrove forest. Mar. Ecol. Progr. Ser. 110, 223-231.

46. Odum, W.E.; Mcivor; C.C.; Smith III, T.J. (1982). The ecology of the mangroves of South Florida: A comunity profile. U.S. Fish and Wildlife Service, Office of Biological Services: Washington, D.C.144p.

47. Peixoto, R.; Chaer, G.M.; Carmo, F.L.; Araújo, F.V.; Paes, J.E.; Volpon, A.; Santiago,G.A.; Rosado, A.S. (2011). Bacterial communities reflect the spatial variation in pollutant levels in Brazilian mangrove sediment. Antonie van Leeuwenhoek, 99, 341-354.

48. Pereira, V.S. (2011). Avaliação fisiológica em microcosmo de Laguncularia racemosa (L.) Gaertn f. associada a consórcio bacteriano em resposta à contaminação por óleo combustível. Dissertação (Mestrado em Biotecnologia Vegetal) - Universidade Federal do Rio de Janeiro.

49. Proffitt, C.E.; Devlin, D.J.; Lindsey, M. (1995). Effects of oil on mangrove seedlings grown under different environmental conditions. Mar. Poll. Bull. 30, 788-793.

50. Roitman, I.; Travassos, L.R.; Azevedo, J.L. (1991). Tratado de Microbiologia. Editora Manole, São Paulo, v. 2. 126p.

51. Santos, H.F.; Carmo, F.L.; Paes, J.E.S.; Rosado, A.S.; Peixoto, R.S. (2010). Bioremediation of mangroves impacted by petroleum. Watter Air Soil Pollut. 216, 329-350.

52. Santos, H.F.; Cury, J.C.; Carmo, F.L.; Rosado, A.S.; Peixoto, R.S. (2010). 18S rDNA sequences from microeukaryotes reveal oil indicators in mangrove sediment. PLOS ONE, 5(8), e12437.

53. Santos, H.F.; Cury, J.C.; Carmo, F.L.; Santos, A.L.; Tiedje, J.; van Elsas, J.D.; Rosado, A.S.; Peixoto, R.S. (2011). Mangrove bacterial diversity and the impact of oil contamination revealed by pyrosequencing: bacterial proxies for oil pollution. PLoS ONE 6(3), e16943.

54. Schaeffer-Novelli, Y. (1995). Manguezal: ecossistema entre a terra e o mar. Caribbean Ecological Research, São Paulo. 64p.

55. Schaeffer-Novelli, Y. (1996). Manguezais da Região Sul do Brasil: estado atual dos conhecimentos e diretivas futuras. $3^{\text {a }}$ Reunião Anual Especial da SBPC. Florianópolis, SC. pp.165-167.

56. Schaeffer-Novelli, Y. (1998). Importância dos manguezais para a conservação dos estoques pesqueiros. Jornal Verde 81, 24.

57. Schaeffer-Novelli, Y.; Cintrón-Molero, G.; Soares, M.L.G.; De-Rosa, T. (2000). Brazilian Mangroves. Aquat. Ecos. Health Manag.. 3, 561-570.

58. Sherman, R.E.; Fahey, T.J.; Howarth, R.W. (1998). Soil-plant interactions in a neotropical mangrove forest: iron, phosphorus and sulfur dynamics. Oecologia, 115, 553-563.

59. Silva, M. (2002). Fungos filamentosos isolados de sedimentos estuarinos que metabolizam hidrocarbonetos aromáticos policíclicos. Campinas, SP. 101p. (Tese de Doutorado. UNICAMP).

60. Sivaramakrishnan, S.; Gangadharan, D.; Nampoothiri, K.M.; Soccol, C.R.; Pandey, A. (2006). Alpha-amylases from microbial sources- An overview on recent development. Food Technol. Biotechnol. 44, 173-184.

61. Skilleter, G.A.; Warren, S. (2000). Effects of habitat modification in mangroves on the structure of mollusc and crab assemblages. J. Exper. Mar. Biol. Ecol. 244, 107-129.

62. Soares, C.A.G.; Maury, M.; Pagnocca, F.C.; Araujo, F.V.; MendonçaHagler, L.C.; Hagler, A.N. (1997). Ascomycetous yeasts from tropical intertidal dark mud of southeast Brazilian estuaries. J. Gen. Appl. Microbiol. 43, 265-272.

63. Sousa, O.V.; Macrae, A.; Menezes, F.G.R.; Gomes, N.C.M.; Vieira, R.H.S.F.; Mendonca-Hagler, L.C.S. (2006). The impact of shrimp farming effluent on bacterial communities in mangrove waters, Ceará, Brazil. Mar. Pol. Bul. 52, 1725-1734.

64. Spalding, M.; Kainuma, M.; Collins, L. (2010). World Atlas of Mangroves. Earthscan, 319p.

65. Sridhar, K.R. (2005). Diversity of fungi in mangrove ecosystems. In: Satyanarayana,T.; Johri, B.N. (ed.). Microbial diversity: Current perspectives and potential applications. I.K. International Publishing House Pvt. Ltd.: New Deli. p.129-148.

66. Taketani, R.G.; Franco, N.O.; Rosado, A.S.; van Elsas, J.D. (2010a). Microbial community response to a simulated hydrocarbon spill in mangrove sediments. J. Microb. 48(1), 7-15.

67. Taketani, R.G.; Yoshiura, C.A.; Dias, A.C.F.; Andreote, F.D.; Tsai, S.M. (2010). Diversity and identification of methanogenic archaea and sulphate-reducing bacteria in sediments from a pristine tropical mangrove. Antonie van Leeuwenhoek 97, 401-411.

68. Trabulsi, L. R. (2002). Microbiologia. 3. ed. Rio de Janeiro: Livraria Atheneu.

69. Wasserman, J.C.; Botelho, A.L.M.; Crapez, M.A.C.; Bispo, M.G.S.; Silva, F.S.; Filgueiras, C.M. (2006). Hidrocarbons e bacterial activity in mangrove sediments from Guanabara Bay, Brazil. Geoch. Brasil. 20(1), 14-25. 